\title{
Front Matter: Volume 9453
}

, "Front Matter: Volume 9453," Proc. SPIE 9453, Window and Dome Technologies and Materials XIV, 945301 (29 May 2015); doi: $10.1117 / 12.2184313$

SPIE. Event: SPIE Defense + Security, 2015, Baltimore, MD, United States 


\section{PROCEEDINGS OF SPIE}

\section{Window and Dome Technologies and Materials XIV}

Brian J. Zelinski

Editor

21-22 April 2015

Baltimore, Maryland, United States

Sponsored and Published by

SPIE 
The papers included in this volume were part of the technical conference cited on the cover and title page. Papers were selected and subject to review by the editors and conference program committee. Some conference presentations may not be available for publication. The papers published in these proceedings reflect the work and thoughts of the authors and are published herein as submitted. The publisher is not responsible for the validity of the information or for any outcomes resulting from reliance thereon.

Please use the following format to cite material from this book:

Author(s), "Title of Paper," in Window and Dome Technologies and Materials XIV, edited by Brian J. Zelinski, Proceedings of SPIE Vol. 9453 (SPIE, Bellingham, WA, 2015) Article CID Number.

ISSN: 0277-786X

ISBN: 9781628415698

Published by

SPIE

P.O. Box 10, Bellingham, Washington 98227-0010 USA

Telephone +1 3606763290 (Pacific Time) · Fax +1 3606471445

SPIE.org

Copyright (C) 2015, Society of Photo-Optical Instrumentation Engineers.

Copying of material in this book for internal or personal use, or for the internal or personal use of specific clients, beyond the fair use provisions granted by the U.S. Copyright Law is authorized by SPIE subject to payment of copying fees. The Transactional Reporting Service base fee for this volume is $\$ 18.00$ per article (or portion thereof), which should be paid directly to the Copyright Clearance Center (CCC), 222 Rosewood Drive, Danvers, MA 01923. Payment may also be made electronically through $\mathrm{CCC}$ Online at copyright.com. Other copying for republication, resale, advertising or promotion, or any form of systematic or multiple reproduction of any material in this book is prohibited except with permission in writing from the publisher. The CCC fee code is $0277-786 \mathrm{X} / 15 / \$ 18.00$.

Printed in the United States of America.

Publication of record for individual papers is online in the SPIE Digital Library.

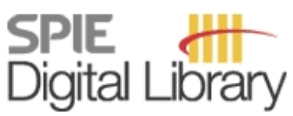

SPIEDigitalLibrary.org

Paper Numbering: Proceedings of SPIE follow an e-First publication model, with papers published first online and then in print. Papers are published as they are submitted and meet publication criteria. A unique citation identifier (CID) number is assigned to each article at the time of the first publication. Utilization of CIDs allows articles to be fully citable as soon as they are published online, and connects the same identifier to all online, print, and electronic versions of the publication. SPIE uses a six-digit CID article numbering system in which:

- The first four digits correspond to the SPIE volume number.

- The last two digits indicate publication order within the volume using a Base 36 numbering system employing both numerals and letters. These two-number sets start with 00, 01, 02, 03, 04, $05,06,07,08,09,0 A, 0 B \ldots 0 Z$, followed by 10-1Z, 20-2Z, etc.

The CID Number appears on each page of the manuscript. The complete citation is used on the first page, and an abbreviated version on subsequent pages. 


\title{
Contents
}

\author{
$\checkmark \quad$ Authors \\ vii Conference Committee
}

\section{SESSION 1 ADVANCES IN MID-WAVELENGTH INFRARED WINDOW TECHNOLOGY}

945302 Highly transparent spinel windows by microwave sintering [9453-1]

945303 Low-loss spinel windows for high-energy lasers [9453-2]

945305 20-inch diameter CHES ${ }^{\circledR}$ sapphire boules [9453-4]

945306 Conformal ALON® windows [9453-5]

945307 Scatter properties of polycrystalline YAG in the visible and near-infrared [9453-6]

\section{SESSION 2 WINDOW AND DOME TECHNOLOGY OVERVIEWS}

945309 A history of semi-active laser dome and window materials (Invited Paper) [9453-8]

9453 OA Weibull analysis and window lifetime prediction: a tutorial (Invited Paper) [9453-9]

\section{SESSION 3 METROLOGY AND FINISHING OF FLAT, FREE-FORM, AND CONFORMAL OPTICS}

9453 OC Development of manufacturing technologies for hard optical ceramic materials [9453-11]

9453 OD Form, figure, and thickness measurement of freeform and conformal optics with noncontact sensors [9453-12]

$9453 \mathrm{OE} \quad$ Freeform optical manufacturing and testing processes for IR conformal window and domes [9453-13]

\section{SESSION 4 NOVEL PROCESSING AND APPLICATIONS OF OPTICAL WINDOWS, DOMES, AND COATINGS}

9453 OK Advances in multi-spectral Diamond-Like Carbon (DLC) coatings [9453-19]

9453 OL Simple optimization method for EMI mesh pattern design [9453-20]

$9453 \mathrm{OM}$ Stress measurement of EFG sapphire using $\mathrm{Cr}^{3+}$ piezospectroscopy [9453-21] 
9453 ON Electronic-band structures and optical properties of transition metal doped Zinc oxide [9453-22]

945300 Role of impactor properties on the computational simulation of particle impact damage in transparent ceramic windows [9453-23]

9453 OP Peridynamic simulation of the effects of coatings, substrate properties, incident angle, and tilt on sand impact damage in transparent ceramic windows [9453-24]

$9453 \mathrm{OR}$ Stress analysis of optical coatings for improved durability and performance of high-end optical components [9453-26]

9453 OS Laser-induced damage threshold prediction of dielectric enhanced mirrors at $1064 \mathrm{~nm}$ [9453-28]

9453 OT Angle resolved backscatter of $\mathrm{HfO}_{2} / \mathrm{SiO}_{2}$ multilayer mirror at $1064 \mathrm{~nm}$ [9453-29]

9453 OV Peridynamic modeling of damage and fracture in EM windows and domes [9453-35] 


\section{Authors}

Numbers in the index correspond to the last two digits of the six-digit citation identifier (CID) article numbering system used in Proceedings of SPIE. The first four digits reflect the volume number. Base 36 numbering is employed for the last two digits and indicates the order of articles within the volume. Numbers start with 00, 01, 02, 03, 04, 05, 06, 07, 08, 09, 0A, 0B...0Z, followed by 10-1Z, 20-2Z, etc.

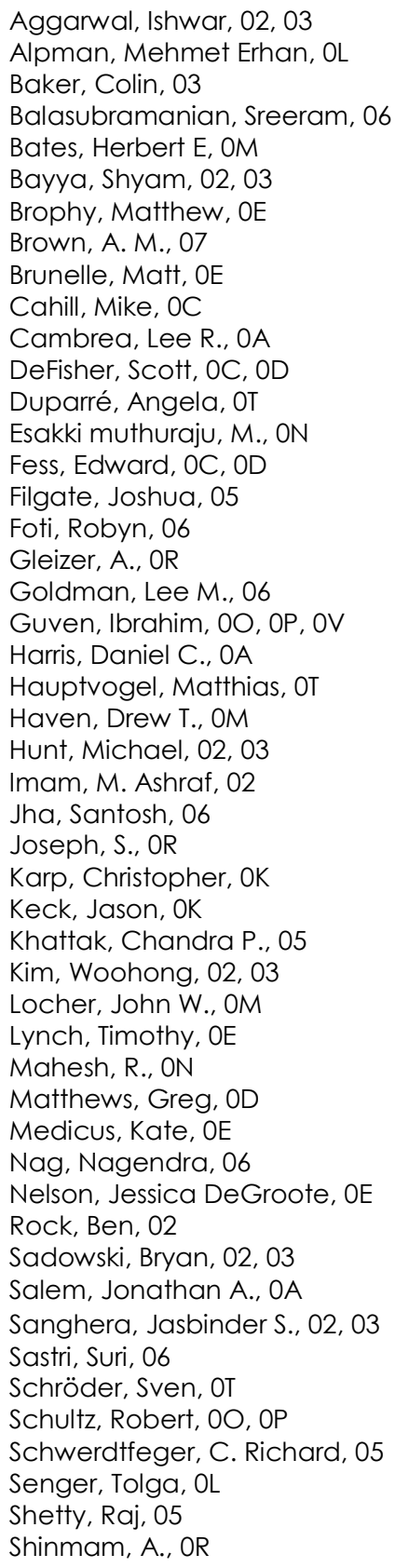

Smith, Mark, 06

Springer, R. M., 07

Sreekanth, T., ON

Sullivan, Roger M., 09

Thomas, M. E., 07

Trost, Marcus, OT

Tune, Shanna, OP

Ullal, Saurabh, 05

Venugopal Reddy, P., ON

Villalobos, Guillermo, 02, 03

Wang, Jue, OS, OT

Wolfs, Frank, OC

Yadlovker, D., OR

Zanella, Steven A., OM

Zelinski, Brian J., OO, OP, OV 
Proc. of SPIE Vol. $9453945301-6$

Downloaded From: https://www.spiedigitallibrary.org/conference-proceedings-of-spie on 26 Apr 2023 Terms of Use: https://www.spiedigitallibrary.org/terms-of-use 


\title{
Conference Committee
}

\author{
Symposium Chair
}

Nils R. Sandell Jr., Strategic Technology Office, DARPA

(United States)

Symposium Co-chair

David A. Logan, BAE Systems (United States)

Conference Chair

Brian J. Zelinski, Raytheon Missile Systems (United States)

Conference Program Committee

Rick Gentilman, Raytheon Integrated Defense Systems (United States)

Daniel C. Harris, Naval Air Warfare Center Weapons Division (United States)

Brian K. Jones, U.S. Army Research, Development and Engineering Command (United States)

John S. McCloy, Washington State University (United States)

Richard Porter, Air Force Research Laboratory (United States)

Michael E. Thomas, Johns Hopkins University Applied Physics Laboratory (United States)

Randal W. Tustison, Consultant (United States)

Martin Winterling, UTC Aerospace Systems (United States)

\section{Session Chairs}

1 Advances in Mid-Wavelength Infrared Window Technology

Rick Gentilman, Raytheon Integrated Defense Systems (United States)

2 Window and Dome Technology Overviews

Brian J. Zelinski, Raytheon Missile Systems (United States)

3 Metrology and Finishing of Flat, Free-Form, and Conformal Optics

Daniel C. Harris, Naval Air Warfare Center Weapons Division (United States)

4 Novel Processing and Applications of Optical Windows, Domes, and Coatings

Michael E. Thomas, Johns Hopkins University Applied Physics Laboratory (United States)

5 Computational Modeling of Optical and Mechanical Properties John S. McCloy, Washington State University (United States) 
Proc. of SPIE Vol. $9453945301-8$

Downloaded From: https://www.spiedigitallibrary.org/conference-proceedings-of-spie on 26 Apr 2023 Terms of Use: https://www.spiedigitallibrary.org/terms-of-use 